\title{
Community and Autonomy: What We Must Protect in the Academy
}

\section{Zelda F. Gamson}

Zelda F. Gamson is senior associate, New England Resource Center for Higher Education, University of Massachusetts-Boston. Tel/fax: (508) 645-3169. E-mail: <gamson@umbsky.cc.umb.edu>.

$\mathrm{N}$ ot so very long ago, saying that colleges and universities need to change was a radical notion. But nowadays, everyone is for changing higher education. Look at the healthcare industry, we have been told again and again in the United States. Why can't higher education restructure like healthcare? Thank heavens we resisted the urge, since there is growing recognition that the changes in the healthcare system have led to high levels of patient and physician dissatisfaction, increasing bureaucratization and the sway of insurance companies and private companies, and at the same time decreasing quality of care. A professor is sometimes described as someone who talks in other people's sleep. Maybe my teacher, David Riesman, has been talking in my sleep lately, telling me to remember his countercyclical teaching- to be suspicious when a lot of people are jumping on the bandwagon for virtue.

So I am suspicious of a lot of people who are talking about changing higher education today. Why? Because I think their kind of change will destroy the most important aspects of higher education, while perhaps marginally improving other things they, like advocates of change in the healthcare system, have been pushing-like increasing accountability and lowering costs. What are the most important aspects of higher education that we should not change? I can capture them in two words: community and autonomy. While community and autonomy are sometimes seen as opposites, I see both as necessary to maintaining the integrity of the academy. I use the terms to describe collective aspects of higher education rather than individual characteristics.

By community I mean relationships among and between the students, faculty, staff, and administrators that support them in their work and reinforce the fact that they are part of a worthy common endeavor that goes beyond their in- dividual needs and interests. These communities overlap and intertwine-within institutions, disciplines, professions, and student groups. Community can be sustained by faceto-face interaction or through mediated interaction over the Internet, telephone, in scholarly papers, and through common projects. Academic communities can be enhanced and augmented by the inclusion of nonacademic groups, such as grassroots leaders, politicians, and artists. Note the appropriateness of including nonacademics in academic communities.

When I bring in the idea of autonomy as central to what we should not change in higher education, I am not talking about the ivory tower divorced from the larger society and its problems. For me autonomy means the ability of institutions - and particularly of the faculty - to carry out the primary mission of higher education in a democracy. That mission is to educate (not just train, as politicians and others urge) the general population for intelligent participation in the public realm and to contribute to the understanding (not just of knowledge, as urged by those who think of education as the marketing of ideas) of how physical, aesthetic, political, and social worlds work. The autonomy of higher education is worth defending because the mission is worth protecting and fighting for.

If someone comes along proposing a change in an institution, public policy, or ways of doing business, I suggest that we all ask whether it will preserve or enhance community and the autonomy of the academy. If the answer to the question is not yes, we should resist the change and fight it tooth and nail. Community and autonomy in higher education are worth defending. We in higher education should hold our heads high and tell the healthcare industry, politicians, bureaucrats, and the media that they might try being more like us!

Note: This essay is based on the author's acceptance speech for the Leadership Award of the Association for the Study of Higher Education, 1999.

\section{On the Europeanization of Higher Education}

\section{Helmut de Rudder}

Helmut de Rudder is on the faculty at the University of Lüneburg, Germany. Address: Universität Lüneburg, Institut für Schul- und Hochschulforschung, 21332 Lüneburg, Germany. E-mail <derudder@uni-lueneburg.de>.

$\mathrm{F}$ ollowing a long period of expansion and structural reforms of national systems after World War II, higher education in Europe has been undergoing considerable changes in the 1980s and 1990s. Some countries are going in similar directions, others are following quite different national policies. Beginning in the 1950s up until the European Union (EU), under the treaties of Maastricht and Amsterdam, and including the euro as a common currency of 11 countries and the reunification of Europe after 1989, the development of European integration is affecting and challenging higher education in Europe in many ways. These developments raise the question whether it is justified to speak of a Europeanization of 
higher education. The easiest answer would be: yes and no, which I suggest is a correct answer. There are discernable but limited tendencies of Europeanization in higher education, but at the same time quite different national systems of higher education prevail.

This phenomenon is not limited to higher education, it is a general European condition. There are tremendous national differences that have grown up over the centuries, and at the same time there have always been emerging, changing and declining European commonalities-such as Christianity, feudalism, capitalism, absolutism, the enlightenment, democracy, colonialism, industrialization, nationalism itself, the welfare state, the rule of law, just to name a few. Social stratification and social change in different industralized European societies have been remarkably similar. It can be said that despite deep national differences and antagonisms, the European nations and societies and their institutions are variations on some basic themes.

\section{Only since the Maastricht Treaty (1992) has general education, under which higher education is subsumed, become a responsibility of the $\mathrm{EU}$.}

That also goes for higher education. One of the enduring European institutions is the university as it originated in the 13th century in Bologna, Paris, and Oxford. The basic model still persists. Over the centuries, it has been exported worldwide and integrated into and adapted to different cultures. The medieval universities were truly European, and they were a system: the disciplinary matrix, curriculum, methods of instruction, degrees, certification, governance and control, organizational structures, and funding arrangements were basically the same. For quite some time, the jus ubique docendi conferred on every Master or Doctor of any university the right to teach at any other university in Europe. And there was one common language: Latin.

In the light of the European university of the past, present European higher education institutions are but a European shadow. (Re-)Europeanization of higher education means several different things at the same time. Policymakers and planners-not just in higher educationtend to think of reality as something they control and have designed, planned, and institutionalized. But Europeanization of higher education is at least as much "what happens anyway" as it is the result of direct political action.

Though the political dimension of European integra- tion has gained in importance especially in the last decade, Europeanization is largely driven by the economy in the context of globalization. That is why the changing European labor market is a major driving force in the Europeanization of higher education: it is increasingly a labor market for higher education graduates in fields like information technologies, business and financial management, and, lately, environmental management ("sustainalibity").

Higher education institutions respond to these challenges by institutionalizing cooperation across national borders (study abroad and common degree programs), by including the European and international dimension in their courses, and by teaching courses in English (so far, that has happened in only a very few cases). Competition between institutions is on the increase, and by Europeanizing and internationalizing programs, institutions become more attractive.

The European Union has become a major player in promoting the Europeanization of higher educationthrough funding. Only since the Maastricht Treaty (1992) has general education, under which higher education is subsumed, become a responsibility of the EU. Mobility of students and academic staff and bi- or trilateral common studies programs (ERASMUS, SOCRATES) are a major activity. In the present phase, the EU concludes contracts directly with higher education institutions, without the mediation of national governments. For this, institutions are expected to develop a European policy. The EU aims at a participation rate in European programs of 10 percent of the student body of the member-states. Not more than .5 percent of the EU budget goes into these programs (versus about 50 percent for agriculture). EU higher education policy is definitely not aiming at creating a European system of higher education but rather at strenthening the European dimension of otherwise national systems and institutions.

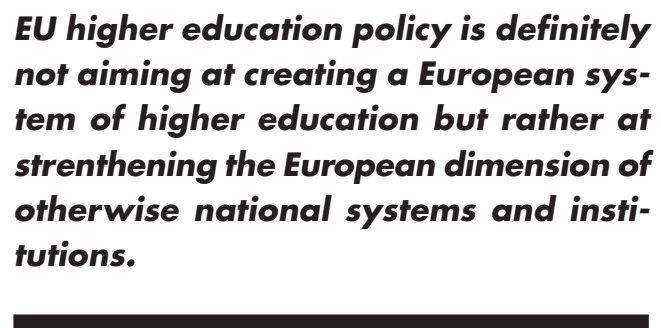

The other major activity of the EU in higher education is contract funding of transnational research in a broad spectrum of applied fields-from garbage disposal to space technology, but hardly for European history or philosophy. The funding is attractive and undoubtetdly sparks re- 
search because academics and research centers get paid for conducting it. But the red tape is immense. National governments (in Germany each of the 16 state governments) and regional networks of universities employ specialists and representatives ("funding brokers") in Brussels to penetrate the funding jungle, to get hold of EU research grants, and to provide the know-how for successful applications. Research money from Brussels has become a major funding source for academia in the member-states of the EU.

\section{Research money from Brussels has be- come a major funding source for academia in the member-states of the EU.}

Starting from the assumption that for higher education European integration does not mean unifying national systems, it follows that for exchange, mobility, and collaborative academic programs the different national systems have to be made more compatible-while preserving their identity. For this, the magic formula is ECTS, the "European Credit Transfer System," a sophisticated network of national governments, national rectors conferences, and the European Rectors' Conference (CRE). For the mutual acceptance of degrees, exams, and course credits, they must be comparable and it must be clear what they mean, what they comprise, and what they are worth in relation to each other. Finally, they must be harmonized. This is the objective of ECTS, and considerable progress has already been made. It is not just a matter of statistical measurement, but also of vested interests and of passing judgments. There is only a thin line between making courses, programs, and degrees compatible and making them more similar.

Besides Europeanization of higher education as a policy, there is a great deal of "creeping Europeanization": common problems are increasingly leading to similar solutions. The financial crisis of all highly industrialized European welfare states and the expansion of higher education ("massification") have led to an underfunding of higher education. Institutions are expected to do more with less, become more efficient, do their own fund raising (that is the new autonomy), be more accountable, and control and improve the quality of what they are doing. In detail, national and institutional solutions differ widely, but the general tendency is basically the same: what we see is a Europeanization of problems and solutions in higher education. National governments have not developed com- mon policies, nor have national higher education systems and institutions coordinated their responses. It is more like people opening their umbrellas when it rains: similar action without coordination.

But similar responses and solutions are greatly advanced by increasing communications within higher education all over Europe. European nongovernmental organizations and associations flourish in higher education, networks grow, and electronic communication is bringing academics and their institutions closer together all the time. Slowly but steadily, something like a European consciousness, not really tangible, seems to be developing in higher education as elsewhere. It is not replacing national identy, however, and the diversity in European higher education is generally appreciated as an asset, not a drawback.

The limits of Europeanization in higher education are obvious. Higher education systems continue to be a responsibility of national governments (or, like in Germany, state governments), which also have to pay for them. EUfunded programs are only a small proportion of institutional budgets. After decades of expansion and regionalization of higher education, most institutions are provincial, training graduates from the region for a regional labor market. The international business administration program is just an added bonus. The large majority of students do not study abroad and could not effectively study in any other language but their own (with notable exceptions in the Netherlands and the Nordic countries). In actual fact, the European or even global labor market for graduates is limited to relatively few professional fields. But the Europeanization of Europe is on the move, the tempo is increasing, and the normative power of the European realities will undoubtedly make higher education in this part of the world more European in this century than it was in the last.

\section{Internet Resource}

For more information on issues related to international and comparative higher education, visit the Center's website, located at: http://www.bc.edu/cihe/ 